\title{
Praktyczne wskazówki dotyczące prawidłowego, nieryzykownego \\ i bezpiecznego dla zdrowia korzystania z technologii interaktywnych
}

DOI: $10.47050 / 65591777.284-311$

Veronica Samara

Powszechnie wiadomo, że technologie interaktywne, takie jak internet i telefon komórkowy, to doskonałe narzędzia służące do komunikacji, nauki, tworzenia, zabawy i pracy. Jak jednak w wypadku każdego rozwiązania, musimy wiedzieć, jak właściwie je użytkować, aby w pełni skorzystać z możliwości, jakie zapewniają, i jednocześnie unikać pułapek. Osoby dorosłe są w stanie ocenić ryzyko i zminimalizować niebezpieczeństwa, z którymi można się spotkać, ale dzieci potrzebują pomocy, aby wykształcić niezbędne umiejętności i zachowania, które pozwolą im cieszyć się wirtualnym światem i wieloma możliwościami, jakie on oferuje. Niniejszy artykuł ma na celu przedstawienie praktycznych wskazówek pomocnych we wspieraniu dzieci w korzystaniu z internetu i interaktywnych technologii w odpowiedzialny, bezpieczny i nieszkodliwy dla zdrowia sposób.

\section{__ Słowa kluczowe:}

\section{prywatność}

informacje online

komunikacja

cyberprzemoc

etyka/reputacja w internecie

nadużywanie

wyłudzanie informacji

kontrola rodzicielska

gry elektroniczne 


\section{Practical tips}

\section{to use interactive technologies \\ in a correct, safe \\ and healthy manner}

DOI: $10.47050 / 65591777.284-311$

Veronica Samara

It is widely known that interactive technologies, such as the Internet and the mobile phone, are amazing tools for communication, learning, creation, fun and work. However, as for every tool, we need to know how to properly use these technologies, in order to enjoy their full potential while avoiding the pitfalls. As adults, we are able to judge and avoid the dangers we may encounter, but children need our guidance, in order to create the necessary skills and behariours, which will allow them to enjoy the online worlds and benefit from their abundance of opportunities. The next pages intend to provide you with practical tips, which will help you in empowering children to use the Internet, and the interactive technologies in general, in a responsible, safe and healthy manner.

\section{Keywords:}

privacy

online information

communication

cyberbullying

online ethics/reputation

excessive use

phishing

parental control

electronic games 


\section{Wprowadzenie}

Powszechnie wiadomo, że technologie interaktywne, takie jak internet i telefon komórkowy, to doskonałe narzędzia komunikacji, nauki, tworzenia, zabawy i pracy. Za pomocą kilku kliknięć dzieci i dorośli mogą wejść w niesamowitą przestrzeń pełną cudów. Ten ogromny wirtualny świat, podobnie jak rzeczywisty, ma jednak również swoje ciemne strony. Osoba dorosła jest $w$ stanie ocenić ryzyko i uniknąć potencjalnych niebezpieczeństw, ale w wypadku dzieci sytuacja przedstawia się zupełnie inaczej.

Odpowiedzialność za ochronę dziecka spoczywa, podobnie jak w świecie rzeczywistym, w rękach jego rodziców i opiekunów. Ochrona nieletnich nie jest jednak prosta. Pożądanym rozwiązaniem nie jest ani całkowity zakaz dostępu do interaktywnych przestrzeni, ponieważ pozbawilibyśmy dziecko cennych narzędzi, ani całkowity brak nadzoru i poleganie na nadziei, że nic złego się nie wydarzy.

Nadszedł czas, aby podjąć działanie. Byłoby wspaniale, gdybyśmy nie musieli wiedzieć, co oznaczają terminy "spam”, „wyłudzanie danych" lub "Instagram". Musimy jednak zapoznać się z nimi dla dobra dzieci, które często pozostawiamy same sobie w internecie, co jest porównywalne $z$ udzieleniem im zgody na włóczenie się po ulicach w środku nocy.

Ponieważ nie potrzebujemy prawa jazdy, aby nauczyć dzieci bezpiecznie przechodzić przez ulicę, w świecie cyfrowym nie musimy być "guru" technologicznym, aby chronić je przed niebezpieczeństwami.

Musimy kierować się tymi samymi zasadami, które obowiązują w realnym świecie. Należy:

$\rightarrow$ nauczyć dzieci odpowiedzialności,

$\rightarrow$ zapewnić im odpowiednie informacje i niezbędną wiedzę,

$\rightarrow$ pomagać im, gdy proszą o pomoc, i zawsze być blisko nich (fizyczna obecność jest ważna),

$\rightarrow$ wzmacniać ich pewność siebie,

$\rightarrow$ mieć stosowną wiedzę i starać się uczyć razem z dziećmi.

Niniejszy artykuł zawiera praktyczne wskazówki pomocne we wspieraniu dzieci w korzystaniu $z$ internetu i interaktywnych technologii w odpowiedzialny, bezpieczny i nieszkodliwy dla zdrowia sposób. 


\section{Wiedza to potęga}

Rodzicu, postaraj się odpowiedzieć na następujące pytania:

$\rightarrow$ Czy zostawiłbyś swoje dziecko samo w parku bez nadzoru?

$\rightarrow$ Czy pozwoliłbyś dziecku, które nie umie pływać, samodzielnie wejść do morza?

$\rightarrow$ Czy pozwoliłbyś swojemu dziecku przejść samodzielnie przez autostradę?

$\rightarrow$ Czy dałbyś dziecku, które nie ma prawa jazdy, kluczyki do samochodu?

$\rightarrow$ Czy powierzyłbyś swoje dziecko obcemu człowiekowi?

$\rightarrow$ Czy pozwoliłbyś dziecku oglądać program telewizyjny, który nie jest odpowiedni dla osób w jego wieku?

$\rightarrow$ Czy pozwoliłbyś dziecku wydać kieszonkowe na gry w kasynie?

$\rightarrow$ Czy dałbyś dziecku swoją kartę kredytową, aby samodzielnie wybrało się na zakupy?

$\rightarrow$ Czy przekazałbyś swoje dane osobowe nieznajomemu na ulicy?

Odpowiedzi twierdzące na powyższe pytania oznaczają w internecie:

$\rightarrow$ Surfowanie bez odpowiedniego nadzoru, w zależności od wieku dziecka.

$\rightarrow$ Surfowanie bez przestrzegania zasad i ograniczeń.

$\rightarrow$ Surfowanie bez świadomości możliwych zagrożeń.

$\rightarrow$ Surfowanie bez odpowiedniej wiedzy.

$\rightarrow$ Komunikowanie się z nieznajomymi w chatroomach i na portalach społecznościowych bez świadomości ryzyka.

$\rightarrow$ Publikowanie danych osobowych bez zastanowienia.

$\rightarrow$ Granie w nieodpowiednie do wieku gry komputerowe.

$\rightarrow$ Celowy lub niezamierzony kontakt dzieci z (nielegalnym) hazardem czy pornografią oraz ogólnie z treściami nieodpowiednimi lub szkodliwymi.

$\rightarrow$ Łatwą zdobycz dla oszustów internetowych.

W związku z tym jest niezwykle istotne, aby rodzice i wychowawcy mieli wiedzę na temat internetu i (dlaczego nie?) nauczyli się w nim poruszać. Poproście dzieci, aby pokazały wam niesamowity świat internetu, a wtedy będziecie w stanie:

$\rightarrow$ Zrozumieć potencjalne zagrożenia oraz objaśnić je dzieciom i nauczyć młodych ludzi, jak ich unikać. 
$\rightarrow$ Porozmawiać z dziećmi o tym, co mogą, a czego nie mogą robić w sieci, oraz ustalić zasady i ograniczenia, wyjaśniając przyczyny, kiedy mówicie "nie" i "musisz".

$\rightarrow$ Zachęcić dzieci do korzystania z internetu w celu właściwego komunikowania się, uczenia się, zabawy i wyszukiwania informacji, z uwzględnieniem odpowiedzialności, dobrego poinformowania i świadomości.

$\rightarrow$ Wzmacniać pewność siebie - pamiętaj, że nawet jeśli dzieci są o wiele sprawniejsze od ciebie w kwestiach technicznych związanych z komputerami, internetem lub telefonem komórkowym, to ty masz doświadczenie życiowe i niezbędne umiejętności krytycznego myślenia, które mogą pomóc im w procesie identyfikacji oraz dywersyfikacji możliwości i zagrożeń cyfrowego świata.

$\rightarrow$ Kiedy tylko możesz, towarzysz dzieciom, gdy korzystają z sieci. Jest to świetny sposób na natychmiastowe omówienie każdej kwestii, która może się pojawić, i zbudowanie zaufania między wami. Wspólne uczenie się jest przyjemnym wyzwaniem. Dołóż zatem starań, by internet stał się rodzinną rozrywką.

\section{Informacje online}

Internet jest ogromną skarbnicą różnych informacji - prawdziwych i wiarygodnych, a także nieprawdziwych i niewiarygodnych, które są dostępne $z$ dowolnego miejsca i o każdej porze. $Z$ tego powodu najważniejsze jest, aby dzieci od najmłodszych lat umiały poruszać się $w$ tej gęstwinie informacji i potrafiły je krytycznie oceniać.

$\rightarrow$ Korzystaj z internetu z dziećmi, traktując go jako cenne narzędzie zdobywania wiedzy i wyszukiwania informacji.

$\rightarrow$ Znajdź odpowiednie strony internetowe dla dzieci, na których mogą szukać rozrywki, informacji lub wiedzy - przeglądajcie je wspólnie.

$\rightarrow$ Naucz dziecko myśleć krytycznie. Każdy, nie tylko ekspert czy naukowiec, może zamieszczać treści w internecie, dlatego rzetelność informacji powinna być sprawdzana w innych wiarygodnych źródłach (takich jak encyklopedie czy czasopisma naukowe). Informacje mogą być mylące lub niezgodne z prawdą.

$\rightarrow$ Naucz dzieci wyszukiwać konkretne informacje online: pokaż im, że umieszczenie frazy wyszukiwania w cudzysłowie jest najbardziej skutecznym sposobem na otrzymanie dopasowanych 
wyników. Jako przykład można pokazać, że jeśli wpiszą w polu wyszukiwania frazę: najwyższy budynek na świecie bez cudzysłowu, wyszukiwarka pokaże wyniki, w których powyższe słowa pojawiają się w dowolnej kolejności, jeśli jednak wpiszą frazę: "najwyższy budynek na świecie", wyszukiwarka pokaże tylko te wyniki, w których wszystkie powyższe słowa pojawiają się dokładnie w takiej kolejności, w jakiej zostały wpisane.

$\rightarrow$ Wpój dzieciom, że powinny natychmiast cię informować o treściach online, które sprawiają, że czują się przestraszone lub skrępowane (na przykład materiały zawierające elementy zastraszania, rasistowskie, ekstremistyczne).

$\rightarrow$ Naucz dzieci odróżniać informacje od reklamy. Za pomocą praktycznych przykładów wyjaśnij dzieciom, że wiele stron internetowych oferujących bezpłatny dostęp do informacji i usług - nawet stron internetowych z grami lub rozrywką - należy do firm komercyjnych, które czerpią zyski z (ukrytej) reklamy, zachęcając dzieci do kupowania towarów lub do pośredniego wpływania na zwyczaje konsumenckie rodzin (na przykład do zakupu produktu danej marki).

\section{Komunikacja i prywatność w internecie}

Internet rozwinął się od prostego narzędzia służącego do publikowania i wyszukiwania informacji do potężnego medium umożliwiające interakcję oraz partycypację społeczną. Należy jednak pamiętać, że sieć jest odpowiednikiem publicznego placu w realnym świecie, gdzie każdy może słyszeć to, co mówimy, jeśli się nie pilnujemy. Dlatego zawsze powinniśmy zachować ostrożność podczas komunikowania się online oraz chronić nasze przestrzenie internetowe i naszą prywatność. Trzeba pamiętać o kilku zasadach:

$\rightarrow$ Pomyśl, zanim opublikujesz. Gdy zamieścisz jakiś materiał w internecie, opuszcza on sferę prywatną i staje się publicznie dostępny w dowolnym miejscu na świecie. Wyjaśnij to dzieciom i zapytaj je, jak to rozumieją. Jeśli masz starsze dzieci, poproś je, aby wyszukały informacje o sobie w internecie ("wygugluj sobie"). Omów z nimi wyniki i zapytaj, czy są zadowolone ze wszystkich informacji, które znalazły na swój temat.

$\rightarrow$ Naucz dzieci, aby chroniły swoje dane osobowe - że nie wolno podawać adresu domowego, numeru telefonu, nazwy szkoły 
lub miejsc, w których spędzają czas. To samo dotyczy danych rodziny, przyjaciół lub osób trzecich.

$\rightarrow$ Wyjaśnij dzieciom, że hasła internetowe są jak klucze do domu: jeśli ktoś je ma, to może wejść do twojej przestrzeni internetowej. Naucz je posługiwać się trudnymi hasłami dostępu do serwisów internetowych, które składają się z co najmniej ośmiu znaków: liter, cyfr i symboli. Hasła muszą być regularnie zmieniane i nie wolno podawać ich nikomu poza rodzicami, nawet najlepszym przyjaciołom. W przeciwnym razie za pomocą tych haseł ktoś może podszywać się pod dziecko w internecie, czytać jego pocztę elektroniczną, zamieszczać nieprawdziwe lub krzywdzące informacje, nękać inne osoby lub rozpowszechniać kłamstwa. Złożone hasło, które nie będzie łatwe do odgadnięcia przez innych, tworzy się bardzo prosto. Pomyśl o czymś, co bardzo lubisz, na przykład: "Spaghetti z czerwonym sosem”. Wykorzystaj pierwsze litery każdego słowa („Szcs”). Zamień ostatnią literę na wielką, literę „z" na "2", dodaj „! " i kilka cyfr, na przykład „12" na końcu: „S2cS!_12". Zgodnie ze stronami internetowymi, na których można sprawdzić stopień bezpieczeństwa hasła (wystarczy wyszukać je online, wpisując w cudzysłowie "jak bezpieczne jest hasło"), złamanie tego ciągu znaków zajęłoby kilka tysięcy lat.

$\rightarrow$ Podczas korzystania $z$ internetu nie na własnych komputerach dzieci muszą pamiętać, że nie powinny odwiedzać stron internetowych, na które trzeba logować się za pomocą hasła, zwłaszcza jeśli łącze na tym urządzeniu nie jest chronione. $W$ przeciwnym razie istnieje ryzyko, że ich dane osobowe mogą zostać skradzione.

$\rightarrow$ Wpój dzieciom, że należy unikać publikowania osobistych zdjęć w internecie. Dotyczy to szczególnie tych fotografii, które przedstawiają sytuacje prywatne, ponieważ nie ma pewności, kto uzyska do nich dostęp. W żadnym wypadku młodzi ludzie nie powinni publikować zdjęć, po których można rozpoznać, gdzie się znajdują, ponieważ w ten sposób obcy ludzie mogą ich zlokalizować i odnaleźć. Poszukaj przykładowego zdjęcia tego typu w internecie i omów z dziećmi cechy, które charakteryzują sytuacje prywatne, lub elementy, na podstawie których można kogoś odnaleźć w świecie rzeczywistym. 
$\rightarrow$ Należy uświadomić dzieciom, jak łatwo jest zmienić oryginalne zdjęcie za pomocą narzędzi edycji dostępnych bezpłatnie w sieci. Czasami odbywa się to oficjalnie, na przykład w związku z kreskówką lub kampanią reklamową. Często jednak następuje to bez zgody osób przedstawionych na zdjęciu, przy naruszeniu ich danych osobowych w takim zakresie, który może nieodwracalnie naruszyć ich godność. Zmienione czy fałszywe zdjęcie może zostać wysłane pocztą elektroniczną, opublikowane na stronie internetowej lub rozsyłane za pomocą telefonów komórkowych do osób na całym świecie, a my nie mamy kontroli nad tym, do kogo ono dotrze.

$\rightarrow$ Bardzo ważne jest wytłumaczenie dzieciom, że nie mogą zamieszczać zdjęć lub filmów przedstawiających inne osoby, a także zdjęć lub filmów przedstawiających je same i z innymi osobami, jeśli nie wyraziły one na to zgody.

$\rightarrow$ Omów z dziećmi kwestię zamieszczania danych osobowych w internecie bez zastanowienia - czyli przy założeniu, że są one skierowane tylko do znajomych - w związku z ukrywaniem przed dorosłymi ich działań w internecie jako ich prawa do prywatności. Wyjaśnij, że nic, co zostało zamieszczone w sieci, nie pozostaje prywatne.

\section{Nieznajomi i internet}

W komunikacji elektronicznej nigdy nie ma pewności co do tożsamości osoby, z którą rozmawiamy (a której nie znamy z kontaktów osobistych), nawet jeśli wyśle nam fotografię lub użyje kamery internetowej. W ten sposób wielu przestępców wykorzystuje anonimowość internetu, aby dotrzeć do nieletnich, podając fałszywe informacje o swojej tożsamości i wieku. Dzięki temu nawiązują z dziećmi przyjaźnie i relacje oparte na zaufaniu w celu zaangażowania ich w praktyki seksualne (grooming - uwodzenie). W związku z tym:

$\rightarrow$ Porozmawiaj z dziećmi o kontaktach z nieznajomymi w internecie. Muszą one zdawać sobie sprawę z tego, że ludzie w sieci, nawet ci, z którymi komunikują się od dłuższego czasu, ale których nie znają w realnym świecie, nie zawsze są tymi, za kogo się podają. Nie zawsze mówią prawdę, dlatego bezwzględnie należy ich traktować jak obcych.

$\rightarrow$ Zapytaj dzieci, czy wszyscy przyjaciele ich przyjaciół - a nawet ich rodzeństwo - w świecie rzeczywistym są również ich przyja- 
ciółmi. Poproś dziecko, aby zastanowiło się nad odpowiedzią, jeśli zapytasz je o "kontakty" online. Dzieci zawsze powinny uważać osoby, które znają wyłącznie w świecie wirtualnym, za obcych.

$\rightarrow$ Jeśli „znajomy" $z$ internetu poprosi dziecko, aby zachowało ich relację w tajemnicy, to znaczy, że coś jest nie w porządku. Czy prawdziwy przyjaciel poprosiłby o coś takiego? Porozmawiaj o tym z dzieckiem i wytłumacz mu, że niezwłocznie musi powiadomić rodzica o takim fakcie.

$\rightarrow$ Wyjaśnij dziecku, że musi być bardzo ostrożne podczas komunikowania się w sieci. Nawet w chatroomie, który jest przeznaczony tylko dla dzieci, nie jest możliwe - przynajmniej obecnie - sprawdzenie, czy wszyscy użytkownicy spełniają kryteria wiekowe. Może się tam znaleźć osoba dorosła, która podaje się za dziecko, próbując wprowadzić innych w błąd.

$\rightarrow$ Dzieci nigdy nie powinny rozmawiać o sprawach osobistych ani podawać danych osobowych w internecie, także wtedy, gdy osobiście znają kim prowadzą konwersację, ponieważ nieznajomi również mogą śledzić taką rozmowę.

$\rightarrow$ Upewnij się, że twoje dziecko nigdy nie umówi się na spotkanie w świecie rzeczywistym z kimś, kogo zna tylko z sieci. Nawet jeśli dziecko twierdzi, że widziało zdjęcie tej osoby, wyjaśnij, że fotografia może nie być prawdziwa, a celem jej zamieszczenia może być chęć wprowadzenia innych w błąd. Trzeba także pamiętać, że nawet jeśli dziecko widziało kogoś przez kamerę internetową, jest narażone na potencjalne ryzyko wpadnięcia w ręce pedofilów lub innych osób, które mogły zatrudnić nieletnich (aby wystąpili przed kamerą internetową) do nawiązania kontaktu z dziećmi.

\section{Tworzenie pozytywnych śladów cyfrowych.}

\section{Zarządzanie własną reputacją $w$ internecie}

Nasz ślad cyfrowy pozostawiamy za każdym razem, gdy korzystamy z internetu, na przykład klikając ikonkę „lubię to" na portalu społecznościowym, gdy odwiedzamy stronę internetową lub wpisujemy hasło do wyszukiwarki. Nasze ślady cyfrowe mogą dużo o nas powiedzieć i pozytywnie lub negatywnie wpływać na sposób, w jaki postrzegają nas inni, nie tylko teraz, ale także w przyszłości. Innymi słowy, nasze ślady cyfrowe mogą kształtować naszą tożsamość i reputację w internecie. 
Poniżej kilka prostych wskazówek, które pomogą dzieciom - i dorosłym - zarządzać własną tożsamością cyfrową i utrzymać dobrą reputację $w$ sieci.

$\rightarrow$ Poszukaj w internecie informacji o sobie. Czy naprawdę wiesz, jakie materiały możesz znaleźć w sieci na swój temat? Wpisz swoje imię i nazwisko do wyszukiwarki, żeby przekonać się, co znajdziesz. Jeśli odkryjesz w sieci treści, które ci się nie podobają, podejmij niezbędne działania, aby je usunąć. Jeśli strony z informacjami o tobie wyświetlają się w serwisach społecznościowych, oznacza to, że każdy może mieć do nich dostęp online. Zalecane jest wprowadzenie zmian w zakładce „Ustawienia prywatności".

$\rightarrow$ Sprawdź ustawienia prywatności. Upewnij się, że wiesz, jakie publikowane przez ciebie informacje są dostępne publicznie na stronach internetowych i w portalach społecznościowych, z których korzystasz. Większość portali zawiera możliwość dokonania ustawień prywatności, co pomaga zarządzać zarówno udostępnianą zawartością, jak i użytkownikami, którzy mają do niej dostęp. Można na przykład zdecydować się na zamieszczanie informacji, które trafiają tylko do twoich znajomych. Nie zapominaj, że treści i ustawienia znajomych mogą również wpływać na twoje ślady cyfrowe.

$\rightarrow$ Pomyśl, zanim klikniesz. Przed zamieszczeniem śmiesznego zdjęcia znajomego w sieci lub napisaniem do kogoś zabawnego tweeta, zastanów się, co by było, gdyby każdy mógł obejrzeć tę fotografię lub przeczytać wiadomość: przyjaciele, znajomi, rodzina, przyszli pracodawcy. Czy chciałbyś, aby inni zamieszczali takie treści na twój temat? Zamieszczaj zatem tylko te materiały, za które nie będziesz się wstydzić w przyszłości. Pamiętaj, że wszystko, co zamieścisz w internecie, zostaje tam na zawsze!

$\rightarrow$ Wyłącz i usuń. Gdy przestaniesz korzystać z serwisu społecznościowego lub ze strony innego rodzaju, dobrym pomysłem jest wyłączenie lub usunięcie konta. Oznacza to, że twoje treści nie będą już aktywne i nie będzie można ich wyszukiwać online. Ochroni cię to również przed ryzykiem włamania na twoje konto.

$\rightarrow$ Zostawiaj pozytywny ślad cyfrowy. Najlepszym sposobem na utrzymanie reputacji cyfrowej jest produktywne wykorzystanie czasu spędzonego $w$ internecie w celu stworzenia pozytywnego śladu cyfrowego. Przykładem może być prowadzenie bloga na tematy, które cię interesują, stworzenie strony społecznościowej 
w celu promowania rodzinnego biznesu, a nawet przygotowanie filmu edukacyjnego, z którego skorzystają inni użytkownicy.

\section{Cyberprzemoc i nękanie w internecie}

Komunikacja za pomocą sieci i telefonów komórkowych ma wiele zalet. Może się ona jednak również wiązać się z nieprzyjemnymi doświadczeniami. Dzieci mogą odbierać wiadomości, które mogą ranić ich uczucia, lub wysyłać treści, które mogą urazić innych.

Cyberprzemoc i nękanie polegają na niewłaściwym użyciu technologii informacyjnych i komunikacyjnych w celu zastraszania lub nękania osób lub grup za pomocą poczty elektronicznej, chatu czy telefonów komórkowych. Wśród dzieci i nastolatków są to coraz bardziej powszechne zjawiska - odnotowuje się ciągły wzrost liczby przypadków nękania uczniów przez uczniów, a nawet uczniów nękających swoich nauczycieli. Takie zachowania mogą obejmować:

$\rightarrow$ Wysyłanie esemesów, wiadomości e-mail lub wiadomości błyskawicznych o nieprzyjemnej treści.

$\rightarrow$ Publikowanie informacji o osobistym charakterze, nieprzyjemnych zdjęć lub wiadomości na temat innych osób na blogach, w serwisach społecznościowych lub w witrynach internetowych innego rodzaju.

$\rightarrow$ Kradzież tożsamości: rozpowszechnianie pogłosek i kłamstw na temat innych lub w cudzym imieniu.

$\rightarrow$ Głuche telefony.

$\rightarrow$ Obraźliwe wiadomości głosowe.

$\rightarrow$ Obraźliwe wiadomości tekstowe mogą być wysyłane na telefony komórkowe przez strony internetowe z użyciem nazwisk i numerów telefonów osób, które nie mają nic wspólnego z takimi esemesami, ale i tak zostają oskarżone o rozpowszechnianie tych wiadomości.

$\rightarrow$ Inną techniką nękania za pomocą technologii cyfrowych jest tworzenie stron internetowych, które są skierowane przeciwko konkretnym osobom lub grupom i które zachęcają innych do szerzenia mowy nienawiści. Nękanie zdarza się również wtedy, gdy uczestnik gry online atakuje ikonę awatara, która odzwierciedla wirtualne "ja" dziecka, na przykład strzelając do niej, kradnąc wirtualną własność lub zmuszając awatara do zachowania się w niepożądany sposób. 
Takie zjawiska mogą sprawić, że młodzi ludzie będą się czuli samotni, nieszczęśliwi, przestraszeni. Mogą stracić pewność siebie i nie chcieć chodzić do szkoły lub spotykać się z przyjaciółmi. Ponadto w skrajnych sytuacjach uporczywe i intensywne nękanie może doprowadzić do nieodwracalnych konsekwencji, łącznie z samobójstwami.

Zastraszanie i nękanie, zarówno elektroniczne, jak i na boisku szkolnym czy placu zabaw, to zachowania społecznie niedopuszczalne. Rodzice, nauczyciele i dzieci muszą być na takie postępowanie uwrażliwieni i gotowi do reakcji. W przeciwieństwie do tradycyjnego zastraszania cyberprzemoc ma tę właściwość, że może mieć wpływ na dziecko nawet wtedy, gdy znajduje się ono w innym miejscu niż sprawca. Osoba nękająca może wysłać zastraszającą wiadomość na adres e-mail lub na telefon komórkowy dziecka z dowolnego miejsca, o dowolnej porze dnia lub nocy.

Żeby ochronić dziecko przed takimi niewłaściwymi zachowaniami można podjąć kilka kroków:

$\rightarrow$ Poznaj otoczenie dziecka - jego przyjaciół, rodziców przyjaciół, nauczycieli i kolegów z klasy.

$\rightarrow$ Zwracaj uwagę na sygnały wskazujące, że twoje dziecko stato się ofiarą cyberprzemocy i nękania w internecie. Mogą nimi być: zwiększony poziom stresu, unikanie przyjaciół, niechęć do pójścia do szkoły lub na ulubione zajęcia, gorsze wyniki w nauce, komentarze, które odzwierciedlają zakłócone relacje.

$\rightarrow$ Dzieci często unikają wspominania o nieprzyjemnych spotkaniach w internecie lub o wiadomościach w telefonie komórkowym. Dlatego koniecznie należy wyjaśnić, że jeśli przydarzy im się coś nieprzyjemnego, to nie one zawiniły i mogą od razu ci o tym powiedzieć.

$\rightarrow$ Naucz swoje dzieci, aby nigdy nie odpowiadały na nieprzyjemne lub obraźliwe teksty. Jeśli otrzymują takie wiadomości lub wiadomości, których nie rozumieją, jeśli widzą nieodpowiednie treści lub obrazy w internecie, otrzymują takie zdjęcia lub filmy na telefon komórkowy lub jeśli są zastraszane, powinny o tym natychmiast poinformować rodzica.

$\rightarrow$ Jeśli twoje dziecko jest ofiarą nękania lub zastraszania, postaraj się ustalić, czy sprawca znajduje się w najbliższym otoczeniu. Często jest to kolega z klasy lub przyjaciel, który znalazł powód atakowania dziecka albo po prostu robi to "dla zabawy", 
bez zastanowienia się nad możliwymi konsekwencjami. W takim wypadku należy porozmawiać z rodzicami takiej osoby, a także z administracją szkoły.

$\rightarrow$ Propagowanie w rodzinie i w społeczności szkolnej środowiska, które nie toleruje zastraszania i nękania. Naucz dzieci tego, że anonimowość w internecie nie oznacza, że można się zachowywać nieodpowiedzialnie. Wszyscy pozostawiamy po sobie cyfrowe ślady, musimy więc zachowywać się uprzejmie, zgodnie z regułami i zasadami moralnymi obowiązującymi w świecie rzeczywistym. Pamiętaj, że nawet twoje dziecko nie zawsze jest aniołem.

$\rightarrow$ Dzieci muszą znać swoje prawa i obowiązki oraz wiedzieć, jak szanować prawa innych osób.

$\rightarrow$ Rozmawiaj często z dziećmi, aby czuły się bezpiecznie i mogły $z$ tobą omówić swoje problemy.

\section{Nie wszystko złoto, co się świeci w internecie}

Internet daje możliwości zawarcia okazyjnych transakcji, ale - podobnie jak w świecie rzeczywistym - działają tu zarówno godne zaufania firmy, jak i oszuści, którzy chcą wykorzystać naiwność klientów. Dlatego ważne jest, aby:

$\rightarrow$ Nieletni nigdy nie robili zakupów online bez nadzoru rodziców. W każdym wypadku należy unikać stron internetowych co do których nie ma pewności, czy działają legalnie i czy są wiarygodne.

$\rightarrow$ Zawsze samodzielnie wpisywać adres internetowy sklepu internetowego, banku, organizacji, które chcesz odwiedzić, aby mieć pewność, że trafiasz na prawdziwą, a nie fałszywą stronę. Upewnij się, że adres, który wyświetla się na pasku przeglądarki, zaczyna się od "https://" ("s" oznacza secure, czyli bezpieczne połączenie). Jeśli nie chcesz podawać danych karty kredytowej, używaj do realizacji transakcji w sieci karty przedpłaconej (prepaid).

$\rightarrow$ Wyjaśnić dzieciom, że nigdy nie powinny brać udziału w quizach lub konkursach online, w których wymaga się przekazania danych osobowych, jeśli nie poprosiły cię wcześniej o zgodę. Dzięki takiej prośbie możliwe jest sprawdzenie, czy jest to witryna godna zaufania, a także przeczytać i zrozumieć warunki wykorzystywania danych osobowych. Działania takie mogą mieć 
na celu oszukanie dzieci, skutkujące nieumyślnym zamówieniem przez nie usług, za które zostaną pobrane wygórowane opłaty, a także uzyskanie zgody na wysyłanie reklam lub nawet wykorzystywanie ich danych do udziału w ankietach albo kampaniach komercyjnych. Istnieją również fałszywe konkursy, których zadaniem jest wyłudzanie wrażliwych danych osobowych (phishing), aby zaszkodzić finansowo rodzinie dzieci.

$\rightarrow$ Wpoić dzieciom, że nie wolno im wypełniać formularzy online bez uprzedniej zgody rodzica, który sprawdzi daną stronę i dokładnie przeczyta odpowiednie informacje (takie jak warunki użytkowania lub polityka prywatności), wyraźnie opisujące sposób wykorzystania przekazanych danych.

\section{Etyka online, własność intelektualna}

Anonimowość w internecie skłania wiele osób do przekonania, że w sieci mogą łamać zasady etyczne występujące w świecie rzeczywistym. Niemniej jednak, jeśli chcemy mieć pozytywne doświadczenia w sieci, musimy zachowywać się odpowiedzialnie i etycznie podczas korzystania z dostępnych usług i szanować innych.

$\rightarrow$ Wszyscy musimy traktować pozostałych użytkowników internetu w taki sam sposób, w jaki chcielibyśmy, aby nas traktowano. Nie obwiniamy ani nie obrażamy nikogo w sieci z myślą, że tylko żartujemy, ponieważ nasz dowcip może nie zostać zrozumiany i może zranić tę osobę. Warto to omówić z dziećmi.

$\rightarrow$ Podobnie jak w świecie rzeczywistym, również w internecie dzieci powinny wiedzieć, że jeśli naruszają zasady, które wiążą się z sankcjami, można je wyśledzić z dowolnego miejsca na świecie dzięki śladom cyfrowym, które wszyscy zostawiamy.

$\rightarrow$ Naucz dzieci, że wolno im odwiedzać tylko legalnie działające strony internetowe. W ten sposób unikną również ryzyka zainfekowania komputera wirusami.

$\rightarrow$ Wyjaśnij dzieciom, że nie mogą przekazywać dalej otrzymanych wiadomości e-mail, które uznają za niedopuszczalne, ponieważ takie działanie jest jak równoznaczne z przesyłaniem niechcianej poczty - spamu.

$\rightarrow$ Wyjaśnij dzieciom znaczenie respektowania własności intelektualnej, podając praktyczne przykłady. Zapytaj, jak postrzegają sytuację, gdy ktoś inny używa wyników ich pracy bez zgody. 
Wyjaśnij dzieciom, że nie mogą po prostu kopiować tekstów ze źródeł internetowych i wykorzystywać ich do odrabiania lekcji, ponieważ takie działanie jest równoznaczne z kradzieżą. Tego rodzaju zachowanie może być niezgodne z prawem i nie wspiera dzieci w rozwijaniu umiejętności poznawczych i krytycznych, które będą im potrzebne w przyszłości. Pojęcie „prawo autorskie” (copyright) nie oznacza zgody na kopiowanie.

$\rightarrow$ Wyjaśnij dziecku, że nie może po prostu pobierać oprogramowania, muzyki, filmów lub innych treści z internetu chronionych prawem autorskim, ponieważ narusza prawo. Istnieje wiele stron internetowych, które udostępniają użytkownikom darmowe materiały, na przykład utwory młodych muzyków, którzy chcą lansować swoją twórczość.

$\rightarrow$ Wyjaśnij po raz kolejny dziecku, że nie może publikować w internecie zdjęć lub filmów wideo, które przedstawiają ich przyjaciół lub inne osoby, jeśli nie wyraziły one zgody na publikację wizerunku. Każdy z nas jest właścicielem „praw intelektualnych” do własnego wizerunku, co musi być w pełni respektowane.

\section{Złośliwe oprogramowanie i niechciane wiadomości}

Codzienne czynności - korzystanie z urządzeń pamięci masowej USB, otwieranie załączników poczty elektronicznej lub pobieranie programów z internetu - mogą stwarzać zagrożenie. Ryzyko to związane jest głównie z rozpowszechnianiem złośliwego oprogramowania (malware), którego celem jest uszkodzenie komputera, kradzież danych osobowych lub bombardowanie użytkownika niechcianymi materiałami reklamowymi. Dlatego konieczne jest zachowanie ostrożności. Poniższe wskazówki pomogą uniknąć sytuacji problemowych.

$\rightarrow$ Zainstaluj na swoim komputerze program antywirusowy i zaporę sieciową (firewall). Program antywirusowy sprawdza wszystkie pliki wraz z załącznikami wiadomości e-mail. W wypadku wykrycia wirusów oprogramowanie natychmiast informuje o tym fakcie i zwykle poddaje kwarantannie zainfekowane pliki lub je naprawia. Program musi być stale aktualizowany i może być również używany do filtrowania stron internetowych. Oprogramowanie antywirusowe jest powszechnie dostępne na rynku lub oferowane przez dostawców usług internetowych. Zapora sieciowa to urządzenie lub oprogramowanie uniemożliwiające 
lub blokujące dostęp do komputera osobom nieupoważnionym. Firewall sprawdza wszystkie pliki przychodzące lub wychodzące z komputera, zajmuje się podejrzanymi elementami, dzięki czemu komputer jest bezpieczny.

$\rightarrow$ Naucz dzieci, że nie wolno otwierać e-maili od osób, których nie znają, lub takich wiadomości, których się nie spodziewają, nawet jeśli zostały wysłane przez ich przyjaciół lub znajomych, ponieważ mogą one zawierać wirusy. Adres osoby, którą znamy, mógł zostać wykorzystany do rozpowszechniania niebezpiecznych plików.

$\rightarrow$ Ostrzegaj dzieci, że nigdy nie wolno otwierać linków, które znajdują się w wiadomościach e-mail, nawet jeśli pochodzą one od znajomych osób, ponieważ linki te mogą prowadzić do stron internetowych, które kradną dane osobowe lub instalują wirusy na komputerze. Poproś je, żeby zawsze wpisywały adres strony internetowej, którą chcą odwiedzić.

$\rightarrow$ Naucz dzieci, żeby nigdy nie odpowiadały na takie e-maile, ponieważ w ten sposób potwierdzają ważność swojego adresu e-mail.

$\rightarrow$ Naucz dzieci zapisywać adresy stron internetowych w sekcji "Zakładki"/,"Ulubione". W ten sposób będą w stanie bardzo łatwo je odnaleźć przy kolejnej wizycie i uniknąć przeniesienia na strony internetowe nieodpowiednie do ich wieku, na przykład przez nieprawidłowe wpisanie adresu internetowego.

$\rightarrow$ Wyjaśnij dzieciom, że muszą chronić swój adres e-mail, unikając zbędnego ujawniania informacji na odwiedzanych przez nie stronach internetowych. To samo dotyczy adresów e-mail rodziny, przyjaciół lub osób trzecich.

$\rightarrow$ Kiedy dzieci publikują swój adres e-mail, mogą go "zmodyfikować" za pomocą znaków, które oszukają silniki śledzące. Na przykład mogą napisać JanKROPKA Nowak AT xy KROPKA pl zamiast Jan.Nowak@xy.pl. Zachęć je do kreatywności przy tworzeniu "nazwy użytkownika". Im dziwniejsze, tym trudniej jest silnikowi je odgadnąć i zacząć wysyłać spam.

$\rightarrow$ Dzieci powinny unikać podejrzanych stron internetowych, a jeśli przypadkowo wejdą na jedną z nich, natychmiast powinny ją opuścić. Jeśli wyskakują okienka z prośbą o wyrażenie na coś zgody, muszą je natychmiast zamknąć (łatwym sposobem jest 
jednoczesne kliknięcie na klawiaturze klawiszy Alt i F4). Nigdy nie należy naciskać przycisków wewnątrz tych okienek.

\section{Nadmierne korzystanie $\mathbf{z}$ internetu}

Zapobiegaj uzależnieniu od internetu dzięki natychmiastowemu rozpoznaniu odpowiednich sygnałów i zwróceniu się do ekspertów o pomoc. Lepiej niż ktokolwiek inny znasz codzienne nawyki swojego dziecka i natychmiast zauważysz zmiany w jego zachowaniu.

Jeśli zaobserwujesz:

$\rightarrow$ podrażnienie, gdy dziecko nie korzysta z internetu,

$\rightarrow$ dłuższy czas korzystania z internetu, niż początkowo zamierzało,

$\rightarrow$ nagłe pogorszenie wyników $w$ nauce,

$\rightarrow$ zaburzenia snu i zmiany w nawykach związanych ze spaniem, zmęczenie i senność,

$\rightarrow$ ograniczoną aktywność fizyczną,

$\rightarrow$ zaburzenia relacji międzyludzkich,

$\rightarrow$ zmianę nawyków dziecka (na przykład odsunięcie się od przyjaciół lub porzucenie ulubionych zainteresowań),

$\rightarrow$ zaniedbanie higieny osobistej,

natychmiast poszukaj pomocy ekspertów, na przykład dzwoniąc na odpowiednią infolinię dla rodziców i specjalistów lub dla dzieci i młodzieży.

Czas, jaki dzieci spędzają przed komputerem i w internecie, nie powinien wpływać na życie rodzinne, obowiązki szkolne, hobby, kontakty z przyjaciółmi i sen.

Naucz także dzieci regularnie robić sobie przerwy w pracy przed komputerem, aby dać odpoczynek oczom.

\section{Filtry i kontrola rodzicielska}

Nawet bardzo małe dzieci mogą czerpać korzyści z internetu, odwiedzając strony w celach rekreacyjnych lub edukacyjnych. Sieć jednak dostarcza różnego rodzaju treści, nie zawsze odpowiednie dla wieku dziecka.

Z tego powodu konieczne jest - zwłaszcza w wypadku młodszych dzieci i tych, które dopiero zaczynają korzystać z internetu - zainstalowanie specjalnych filtrów i aktywowanie mechanizmów kontroli rodzicielskiej. 
Filtry są programami regulującymi dostęp do informacji lub usług w sieci zgodnie z ustalonymi kryteriami. Mogą być zainstalowane na komputerze użytkownika, na serwerze należącym do organizacji (na przykład szkoły) lub na urządzeniach dostawcy usług internetowych. Działają na różne sposoby: mogą ostrzegać o problematycznych stronach internetowych, rejestrować ruchy użytkownika w sieci, blokować podejrzane strony, a nawet całkowicie wyłączyć komputer.

Filtry mają głównie na celu ochronę nieletnich dzięki niezawodnej barierze uniemożliwiającej dostęp do treści niedopuszczalnych, treści uznawanych za niebezpieczne lub materiałów, które mogą powodować problemy w rozwoju dzieci. Jednocześnie nie blokują dostępu do treści dostosowanych dla dzieci i młodzieży.

Na przykład filtr, którego celem jest blokowanie stron internetowych zawierających materiały o charakterze seksualnym, nie powinien blokować witryn dotyczących miasta Essex (EsSEX) - innymi słowy, powinien być na tyle inteligentny, aby blokowanie odbywało się przy użyciu rozbudowanych metod rozpoznawania szkodliwych stron. Ponadto filtr nie powinien być bardziej restrykcyjny niż to konieczne, aby nie blokował niewinnych treści. Mogłoby dojść do sytuacji, gdy blokowane byłyby informacje na temat historii drugiej wojny światowej, ponieważ takie wyszukiwanie zapewne prowadziłoby do stron internetowych z opisami przemocy.

Jeśli chodzi o kontrolę rodzicielską, filtry rozpoznają również dane wychodzące z komputera, na przykład w celu uniemożliwienia dzieciom publikowania danych osobowych, takich jak imię i nazwisko, adres domowy lub szkoły, informacje o kartach kredytowych. Ten rodzaj filtrowania jest bardzo ważny z punktu widzenia ochrony młodych użytkowników. W internecie i na rynku dostępnych jest wiele programów tego rodzaju.

\section{Istotne wskazówki dotyczące filtrów i kontroli rodzicielskiej:}

$\rightarrow$ Utwórz oddzielne konto użytkownika dla każdego dziecka w systemie operacyjnym (na przykład Windows, Linux, Mac OS), następnie aktywuj opcje kontroli rodzicielskiej w zależności od wieku każdego dziecka. Jeśli nie wiesz, jak to zrobić, poproś o pomoc specjalistę, na przykład pracownika sklepu, w którym kupiłeś komputer.

$\rightarrow$ Wykorzystaj w pełni opcje kontroli rodzicielskiej oferowane przez system operacyjny komputera. W ten sposób będziesz 
mógł chronić prywatność i bezpieczeństwo dzieci w sieci, ustawiać i monitorować czas, jaki spędzają przed komputerem, definiować strony internetowe, które będą mogły odwiedzać, lub wybierać gry, których będą mogły używać.

$\rightarrow$ Zaznacz ulubione strony internetowe swojego dziecka za pomocą opcji „Zakładki" lub „Ulubione” (dostępnych w przeglądarce). W ten sposób dziecko będzie mogło odwiedzać ulubione strony bez konieczności ponownego wpisywania adresu lub korzystania z wyszukiwarek.

$\rightarrow$ Filtry mogą być cennym narzędziem chroniącym nieletnich przed szkodliwymi treściami. Trzeba jednak zawsze pamiętać, że działają one tylko pomocniczo i prawdopodobnie są skuteczne tylko w wypadku dzieci w młodszym wieku. Każdy filtr, który można włączyć, może również być wyłączony przez bystrych, młodych użytkowników, którzy często potrafią ukrywać ślady swojej aktywności. Tylko w sytuacji, gdy wiesz, jak obsługiwać komputer i zainstalowane na nim programy, będziesz w stanie wykryć takie działania.

$\rightarrow$ Żaden program nie zastąpi rozmowy z dzieckiem. Środki techniczne nie są panaceum, a czasami mogą tworzyć fałszywe poczucie bezpieczeństwa, jeśli nie stosujemy ich w połączeniu ze zdrowym rozsądkiem. Nadzór edukacyjny w domu, podobnie jak w szkole, wraz z komunikacją i ze świadomością ryzyka, jest korzystniejszy od barier technologicznych, ponieważ przyczynia się do właściwej edukacji nieletnich, zrozumienia problemów i rozwijania krytycznego myślenia $w$ radzeniu sobie $z$ nimi.

Z tego powodu należy być blisko dzieci korzystających z internetu, zwłaszcza tych w młodszym wieku. Jest to świetny sposób na natychmiastowe omówienie każdej kwestii, która może się pojawić, a także okazja do zbudowanie zaufania.

\section{Wybierz grę odpowiednią dla każdego dziecka}

W celu ochrony nieletnich przed nieodpowiednimi aplikacjami stworzono Ogólnoeuropejski System Klasyfikacji Gier - PEGI (Pan European Game Information). System składa się z dwóch elementów: oznaczeń wiekowych i opisów treści. Większość dostępnych na rynku gier komputerowych ma etykietę PEGI z przodu i z tyłu pudełka, w których są sprzedawane. 
$\rightarrow$ Oznaczenia wiekowe. System składa się z pięciu oznaczeń: PEGI 3, PEGI 7, PEGI 12, PEGI 16 i PEGI 18. Wskazują one minimalny wiek użytkowników, dla których odpowiednia będzie treść gry.

$\rightarrow$ Opisy treści. Stosowanych jest osiem opisów (deskryptorów): wulgarny język, dyskryminacja, narkotyki, strach, hazard, seks, przemoc i zakupy w grze.

Chociaż klasyfikacja PEGI to jedynie wskazówka i zalecenia dla kupujących, należy ją brać pod uwagę, gdy chcemy zapewnić bezpieczeństwo dzieciom. Klasyfikację gry można znaleźć, wyszukując jej tytuł na stronie internetowej PEGI (pegi.info/pl)1.

Ilustracja 1. Wyszukiwanie klasyfikacji gry na stronie internetowej PEGI

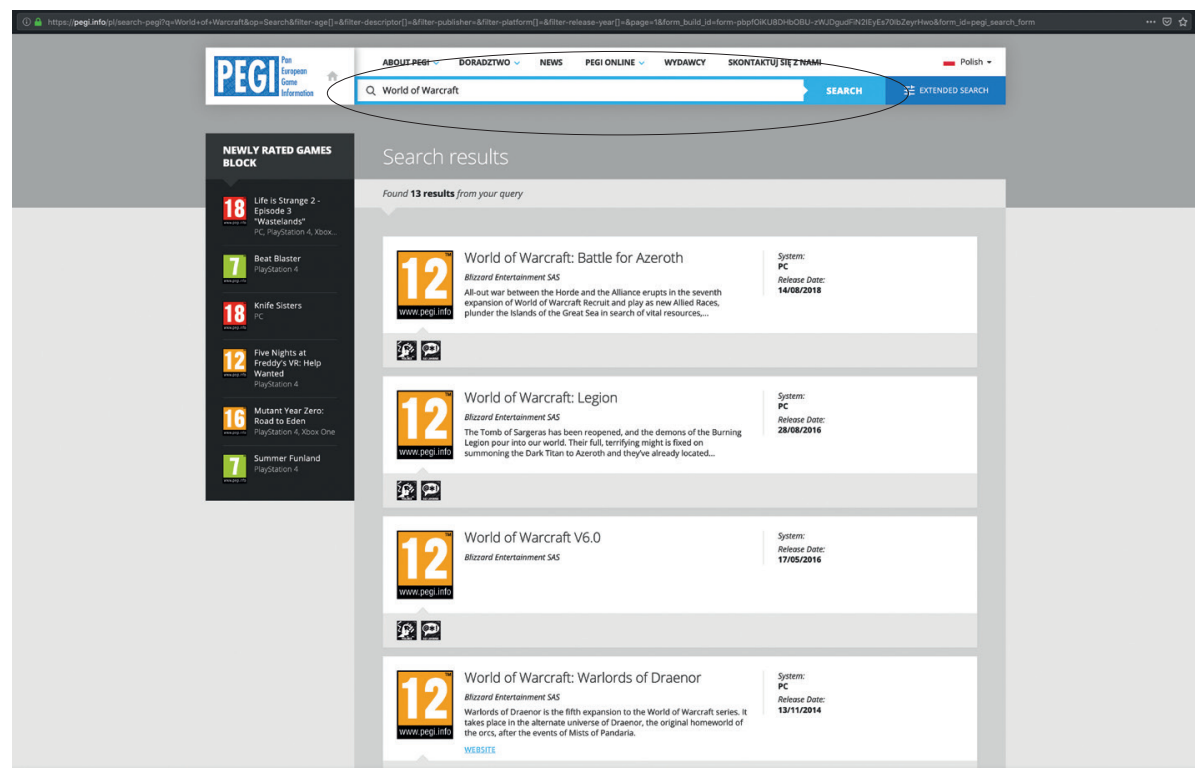

Na przykład po wpisaniu tytułu World of Warcraft otrzymujemy listę 13 dostępnych wersji gry z ikoną oznaczenia wiekowego i opisem treści dla każdej z nich. Ilustracja 1 pokazuje cztery z dostępnych 13 wyni- 
ków - widoczne są ikony ograniczenia wieku do 12 lat oraz informacje, że aplikacja zawiera przemoc i wulgarny język.

\section{Podstawowe wskazówki dotyczące korzystania z gier komputero- wych przez dzieci:}

$\rightarrow$ Przed zakupem gry upewnij się, że jej zawartość jest odpowiednia dla twojego dziecka (system PEGI).

$\rightarrow$ Ustal zasady dotyczące czasu korzystania z gier przez dzieci.

$\rightarrow$ Spędzaj część czasu wolnego, grając z dziećmi. Jeśli skomplikowane środowiska wirtualne są ci obce, poproś dzieci, aby cię w nie wprowadziły. Chętnie ci pokażą.

$\rightarrow$ Śledź zwyczaje dzieci podczas zabawy, dzięki temu będzie możliwe natychmiastowe zidentyfikowanie oznak nadmiernego zaangażowania lub uzależnienia.

$\rightarrow$ Omówcie treść gier - ustalcie, które elementy przypominają rzeczywistość i co szczególnie podoba się dzieciom w tych grach.

$\rightarrow$ Ucz dzieci odpowiedzialności za wykorzystanie ich danych osobowych, również podczas korzystania z gier online.

$\rightarrow$ Zachęcaj do krytycznego myślenia. Dzieci są bardzo dochodową grupą docelową dla reklamodawców internetowych, dlatego powinny być zawsze czujne, aby umieć odróżnić informacje od treści reklamowych w wirtualnych światach.

$\rightarrow$ Gdy dzieci biorą udział w rozgrywkach online dla wielu użytkowników:

- wybieraj strony internetowe z surowymi zasadami i moderatorem,

- naucz dzieci, że nie wolno podawać danych osobowych innym graczom,

- przestrzegaj, że nie wolno im się zgadzać na spotkanie w prawdziwym świecie z innymi graczami, których znają tylko z internetu,

- zachęć dzieci do tego, żeby natychmiast informowały cię o wypadkach napastowania, zastraszania, używania nieodpowiedniego języka, publikowania nieprzyjemnych treści lub wysyłania przez innych graczy zaproszeń do spotkania w realnym świecie.

$\rightarrow$ Nie korzystajcie z gry, która wywołuje dyskomfort u ciebie lub dziecka. 


\section{Wlaściwe korzystanie z telefonu komórkowego}

Telefony komórkowe są obecnie powszechnym środkiem komunikacji. Prawie wszystkie komercyjnie dostępne urządzenia oferują wiele usług wykraczających poza konwencjonalne rozmowy, na przykład wysyłanie tekstów (esemesy), robienie i udostępnianie zdjęć, przesyłanie wiadomości multimedialnych (ememesy), odtwarzanie muzyki. Szeroko stosowane smartfony zapewniają również pełny dostęp do internetu.

Ponieważ telefon komórkowy jest narzędziem osobistym, kontrola rodzicielska nad korzystaniem z niego przez dziecko nie jest łatwa. Urządzenia są dla wielu dzieci oznaką statusu społecznego, a także narzędziem, bez którego nie wyobrażają sobie życia.

Problemy, które mogą wynikać z niedbałego lub niewłaściwego korzystania z telefonu komórkowego, są dość poważne, spośród nich można zaś wyróżnić: możliwość niekontrolowanego dostępu do nieodpowiednich materiałów, nękanie przez osoby nieprzyjazne ludzi pedofilów, wykorzystanie danych osobowych przechowywanych w pamięci ukradzionego telefonu oraz przesyłanie niechcianych materiałów reklamowych do dzieci, które nie wiedzą, co z nimi zrobić. W związku $z$ tymi zagrożeniami trzeba podjąć takie same środki bezpieczeństwa jak przy korzystaniu z internetu. Poniżej kilka ogólnych wskazówek.

$\rightarrow$ Uzgodnij z dzieckiem zasady, których powinno przestrzegać podczas korzystania z telefonu komórkowego, zwłaszcza w wypadku usług online.

$\rightarrow$ Uświadom mu potencjalne zagrożenia, zwłaszcza te związane z kontaktami osobistymi, i naucz je, jak takie niebezpieczeństwa rozpoznawać.

$\rightarrow$ Przestrzegaj, aby dziecko nie odpowiadało na wiadomości otrzymane od nieznajomych lub na takie, które wydają się dziwne.

$\rightarrow$ Naucz dziecko, aby nie podawało numeru telefonu komórkowego lub danych osobowych ludziom, których nie zna i którym nie ufa.

$\rightarrow$ Jeśli podejrzewasz, że dziecko jest nękane przez kogoś przez telefon komórkowy, zapytaj je o to i poproś, żeby powiedziało, czy rzeczywiście tak się dzieje. W takim wypadku należy zachować wiadomości, zanotować datę i godzinę połączenia oraz skontaktować się z operatorem sieci komórkowej lub policją.

$\rightarrow$ Wymagaj od dziecka przestrzegania zasad dobrego zachowania podczas korzystania z telefonu komórkowego. 
$\rightarrow$ Powiedz dziecku, aby nie zostawiało telefonu komórkowego na widoku publicznym i nie trzymało go $w$ ręku, kiedy nie jest to konieczne. Nie powinno również umieszczać urządzenia w kieszeniach ani w plecakach, które pozostają poza zasięgiem jego wzroku.

$\rightarrow$ Przestrzeż dziecko, żeby nigdy nie dawało telefonu komórkowego osobie nieznajomej, która chce wykonać "pilne" połączenie. Ale jeśli sytuacja staje się groźna dla dziecka, to lepiej, żeby dało telefon komórkowy, nawet jeśli zostanie skradziony. Bezpieczeństwo i nienaruszalność cielesna dziecka są o wiele ważniejsze od utraty urządzenia, a kradzież można natychmiast zgłosić na policję.

$\rightarrow$ Upewnij się, że dziecko wie o tym, że musi otrzymać zgodę swoich przyjaciół lub znajomych przed zrobieniem im zdjęcia. Nie powinno fotografować nieznajomych.

$\rightarrow$ Naucz dziecko, aby nie wysyłało ani nie publikowało za pośrednictwem telefonu komórkowego zdjęć przedstawiających sytuacje, które mogą spowodować problemy teraz lub w przyszłości.

$\rightarrow$ Przypominaj dziecku, że nigdy nie powinno wysyłać zdjęć nieznajomym przez telefon komórkowy lub zamieszczać ich w internecie. W żadnym wypadku nie powinno wysyłać fotografii innych osób, jeśli one o tym nie wiedzą i nie wyraziły na to zgody.

$\rightarrow$ Upewnij się, że dziecko nie będzie odpowiadało na reklamy lub informacje od nieznanych nadawców. W żadnym wypadku nie powinno przesyłać tych wiadomości innym osobom.

$\rightarrow$ Naucz dziecko chronić dane osobowe, żeby nigdy nie wpisywało numeru telefonu komórkowego $w$ formularzach i wnioskach (online lub innych). Takie działanie może oznaczać, że dziecko wyraża zgodę na zawarcie umowy z firmą lub organizacją, która obsługuje tego typu ankiety. Jeśli zechce to zrobić, powinno poinformować któregoś z rodziców, aby mógł się zapoznać ze sprawą i dowiedzieć, w jaki sposób zostaną wykorzystane wymagane dane.

$\rightarrow$ Wyjaśnij dziecku, że powinno być bardzo ostrożne wobec treści pobieranych na telefon komórkowy. Dowiedz się, czy udostępnia znajomym za pomocą telefonu komórkowego (lub internetu) tego rodzaju materiały. Należy pamiętać o tym, że pobie- 
ranie niektórych informacji może być niezgodne z przepisami prawa autorskiego.

$\rightarrow$ Naucz dziecko wyłączać Bluetooth, kiedy z niego nie korzysta, oraz tego, żeby upewniało się, że jest wyłączony w miejscach publicznych, ponieważ dane przechowywane w telefonie mogą zostać skradzione.

\section{Akronimy i emotikony}

W chatroomach, sieciach społecznościowych, wiadomościach e-mail, a nawet w telefonach komórkowych często używa się skrótów słów lub zwrotów - akronimów (głównie w języku angielskim i pisanych wielkimi literami). W tabeli 2 można znaleźć kilka popularnych akronimów używanych przez dzieci w komunikacji online, z którymi warto się zapoznać.

Tabela 2. Popularne akronimy używane przez dzieci w komunikacji online

\begin{tabular}{|c|c|}
\hline$\wedge 5$ & (high 5) - piątka/przybij piątkę \\
\hline 24/7 & 24 godziny na dobę, 7 dni w tygodniu \\
\hline ANW & (anyway) - w każdym razie \\
\hline ASAP & (as soon as possible) - jak najszybciej \\
\hline ASL lub A/S/L & (age, sex, location) - wiek, płeć, miejsce zamieszkania \\
\hline AFK & (away from keyboard) - z dala od klawiatury \\
\hline $\mathrm{B} / \mathrm{C}$ & (because) - ponieważ \\
\hline $\mathrm{B} 4 \mathrm{~N}$ & (bye for now) - na razie \\
\hline BBL & (be back later) - będę później \\
\hline BRB & (be right back) - zaraz wracam \\
\hline BTW & (by the way) - przy okazji \\
\hline C & (see?) - rozumiesz, widzisz? \\
\hline $\mathrm{CU}$ & (see you) - do zobaczenia \\
\hline CUL & (see you later) - do zobaczenia później \\
\hline $\mathrm{F} 2 \mathrm{~F}$ & (face to face) - twarzą w twarz \\
\hline FAQ & (frequently asked questions) - najczęściej zadawane pytania \\
\hline JJ & (just joking) - tylko żartuję \\
\hline GL & (good luck) - powodzenia \\
\hline GM & (good morning) - dzień dobry \\
\hline G2G/GTG & (got to go) - muszę lecieć \\
\hline IDK & (I don't know) - nie wiem \\
\hline L8R & (later) - później \\
\hline LMIRL & (let's meet in real life) - spotkajmy się w realu \\
\hline
\end{tabular}




\begin{tabular}{l|l}
\hline LOL & (laugh out loud) - uśmiałem się \\
\hline LU4E & (love you forever) - kocham cię na zawsze \\
\hline NP & (no problem) - nie ma problemu \\
\hline PAL & (parents are listening) - rodzice słuchają \\
\hline PAW & (parents are watching) - rodzice patrzą \\
\hline PLS & (please) - proszę \\
\hline POS & (parent over shoulder) - rodzic patrzy przez ramię \\
\hline S$^{\wedge}, S^{\prime} U P$ & (what's up?) - co słychać? \\
\hline SRY & (sorry) - przepraszam \\
\hline THNX & (thanks) - dzięki \\
\hline TTYL & (talk to you later) - pogadamy później \\
\hline W8 & (wait) - zaczekaj \\
\hline WB & (welcome back) - witamy z powrotem \\
\hline WTGB & (want to go private?) - chcesz przejść na priva? \\
\hline WYCM & (will you call me?) - zadzwonisz?
\end{tabular}

Emotikony to piktogramy mające symbolizować określony wyraz twarzy i emocje. Składają się ze znaków, które - odczytywane z głową odwróconą o 90 stopni w lewo - przypominają piktogram "buźka". Na przykład emotikon :-) oznacza uśmiech. W tabeli 3 ujęto wybrane emotikony szeroko stosowane $w$ komunikacji elektronicznej:

Tabela 3. Wybrane emotikony szeroko stosowane w komunikacji elektronicznej

\begin{tabular}{l|l} 
:-) uśmiech & $:-($ smutek \\
\hline ;-) uśmiech z przymrużeniem oka & $:-$ O zdziwienie \\
\hline :-p pokazanie języka & $0:-)$ anioł \\
\hline :- $^{\star}$ pocałunek & $:-\#$ zachowanie tajemnicy \\
\hline$\%-$ I zdezorientowany & >:-( złość \\
\hline 8-) noszę okulary & QQ łzy
\end{tabular}

\section{Zawarcie rodzinnej lub szkolnej umowy dotyczącej korzystania z internetu}

Ważne jest, aby dzieci rozumiały i przestrzegały ogólnych zasad odpowiedzialnego, bezpiecznego i nieszkodliwego dla zdrowia korzystania $z$ internetu, telefonu komórkowego lub innych interaktywnych technologii. Warto omówić z dziećmi 16 zasad i uszeregować je indywidualnie z każdym dzieckiem lub w ramach zajęć w klasie. Następnym kro- 
kiem może być podpisanie z dzieckiem (przez rodzica) lub z całą klasą (przez wychowawcę) specjalnej umowy, oznaczonej datą i umieszczonej w powszechnie dostępnym miejscu. Wszystkie zasady są jednakowo ważne, jednak zawsze warto wysłuchać przemyśleń dzieci.

1. Nigdy nie ujawniam danych osobowych $w$ internecie, $w$ tym prawdziwego imienia i nazwiska, adresu domowego, numeru telefonu, nazwy szkoły. Tak samo postępuję z danymi osobowymi mojej rodziny, przyjaciół i innych osób.

2. Powiadamiam rodzica/wychowawce, jeśli przeczytam w internecie coś, co mnie niepokoi, wydaje się podejrzane lub jest zbyt atrakcyjne, by mogło być prawdziwe.

3. Traktuję innych użytkowników internetu w sposób, w jaki chciałbym, żeby mnie traktowano.

4. Nie obwiniam nikogo ani nie obrażam w żartach, ponieważ moje działanie może zostać źle zrozumiane.

5. Mogę się dobrze bawić w wirtualnym świecie, ale zawsze odróżniam go od świata rzeczywistego.

6. Nigdy nie spotykam się w realnym świecie z ludźmi, których znam tylko $z$ internetu, ponieważ są to obce osoby.

7. Zawsze porównuję treści, które znajduję w internecie, z innymi źródłami, na przykład książkami, gazetami, czasopismami.

8. Nigdy nie robię zakupów $\mathbf{w}$ sieci bez asysty rodzica i nigdy nie zawieram transakcji na stronach internetowych, jeśli nie mam pewności, czy są one godne zaufania.

9. Regularnie robię przerwy od komputera i internetu, by dać odpocząć oczom.

10. Nie proszę innych o ujawnianie danych osobowych w internecie.

11. Nie interesują mnie treści tylko dla dorosłych, wchodzę na strony internetowe odpowiednie dla osób w moim wieku.

12. Kopiowanie $z$ internetu może być nielegalne. Nie kopiuję treści materiałów, które znajduję w sieci, do mojej pracy domowej, ponieważ takie działanie jest jak kradzież. Przed wykorzystaniem materiału zawsze proszę o zgodę jego autora.

13. Nie pobieram muzyki i filmów ze stron internetowych, chyba że jestem pewien, że są to witryny godne zaufania, że muzyka i filmy są oferowane za darmo i że nie naruszam praw autor- 
skich innych osób. Uczciwe strony internetowe jasno określają, czy ich usługi są bezpłatne, czy też wymagają opłaty.

14. Korzystając $z$ internetu nie na swoim komputerze, nie wchodzę na strony internetowe, na które trzeba zalogować się za pomocą hasła, zwłaszcza jeśli połączenie internetowe z takiego komputera nie jest chronione. W przeciwnym razie istnieje ryzyko, że moje dane osobowe mogą zostać skradzione.

15. Nie przesyłam dalej otrzymanej wiadomości e-mail, której treść uważam za nie do przyjęcia, ponieważ takie działanie jest równoznaczne z przesyłaniem spamu.

16. Chronię moje hasła i nie ujawniam ich nikomu, nawet najlepszym przyjaciołom. Zmieniam hasła regularnie, a także natychmiast wtedy, gdy podejrzewam, że ktoś je ukradł (przechwycił)².

\section{Zakończenie}

Technologie interaktywne wyznaczyły nowe horyzonty w zakresie zarówno wiedzy, jak i komunikacji. Każdy z nas powinien znać pozytywne aspekty, jakie się z nimi wiążą, a także umieć chronić się przed potencjalnymi zagrożeniami. Jako rodzice i nauczyciele mamy obowiązek dostarczać dzieciom informacji, żeby mogły również korzystać z nowoczesnych narzędzi bez żadnych nieprzyjemnych niespodzianek.

Dzieci muszą być odpowiednio edukowane na temat tego, co mogą, a czego nie powinny robić w sieci. Jest to ważne, gdy udzielamy im porad lub wyjaśniamy powody niektórych zakazów. Na przykład, kiedy mówimy dziecku, że nie wolno otwierać e-maili od nieznanych nadawców, musimy wyjaśnić dlaczego jest to ważne (wiadomości mogą zawierać wirusy).

Dzieci muszą wiedzieć, że należy traktować ludzi w internecie tak samo jak w świecie rzeczywistym, czyli z szacunkiem, oraz że należy przestrzegać zasad dobrego wychowania. Ważne, żeby umiały ocenić, które informacje w sieci są prawdziwe, a które fałszywe, co jest dobre, a co złe.

Na koniec należy stwierdzić, że kluczowe znaczenie ma budowanie zaufania w rodzinie i w szkole. Dzięki temu dzieci będą zwracać się do swoich rodziców i nauczycieli o pomoc, kiedy będą jej potrze- 
bować, wiedząc, że dorośli zawsze pomogą im w sprawie ich działań $w$ internecie.

Niezwykle ważną rolę do odegrania ma także państwo. Władze powinny wprowadzać odpowiednie przepisy i środki, które zagwarantują dobro nieletnich w świecie cyfrowym, zarówno na poziomie krajowym, jak i globalnym. Bez odpowiednich systemów kontroli, świat przemocy, pornografii, hazardu, a także niedopuszczalne strony internetowe nadal będzie dostępny dla wszystkich dzieci. 